\title{
Lecturas para Felipe II. La colección de novelas de Pedro de Salazar como regimiento de príncipes y la legitimación de lo ficcional
}

\author{
Valentín Núñez Rivera \\ Universidad de Huelva \\ vnrivera@uhu.es
}

Recepción: 25/02/2015, Aceptación: 17/04/2015, Publicación: 22/12/2015

\begin{abstract}
Resumen
La intención de este artículo es caracterizar las Novelas de Pedro de Salazar (ca. 15601565), recientemente publicadas, como un regimiento de principes. Para ello, después de contextualizar la colección de novelas en la tradición medieval, se analizan las diversas estrategias con que el autor, desde su perspectiva de historiador, pretende dignificar un género de escritura desprestigiado en ese momento. La más importante de estas técnicas consiste en dedicar el conjunto al propio Felipe II, además de proponer como protagonista del marco narrativo al rey godo Ervigio y conformar muchos de los relatos con argumentos propios de la ficción bizantina. Finalmente se establecen las relaciones existentes entre este programa literario y la imprenta, las bibliotecas nobiliarias y hábitos lectores en la España del Siglo de Oro, en orden a definir el estatuto de la ficción frente a otros géneros literarios.
\end{abstract}

Palabras clave

regimiento de príncipes; colección de novelas; Pedro de Salazar; paratextos

\begin{abstract}
Readings for Felipe II: Pedro de Salazar and his collection of novels as treatises of government The aim of this paper is to cast light on the role of the novels by Pedro de Salazar (ca. 1560-1565), recently published, as treatises of government. The paper is organized as follows. First, I will discuss the links between this collection of novels and the medieval tradition. Second, I will highlight several strategies followed by the author (which build on his own expertise as historian) to dignify a narrative genre that was greatly discredited at his time. Third, I will delve into three of such strategies: he dedicates his collection
\end{abstract}


of novels to the king Philip II; he builds the narrative frame around the character of the king Ervigio; and finally, for many of his novels he uses arguments that are close to the topics of the Byzantine novels. Finally, I will consider in some detail the links between this literary program and the printing activities, the nature of the noble libraries, and the reading habits of the Spanish Golden Age, in order to conclude some important facts about the status of the fictional prose among the literary genres of this time.

\section{Keywords}

Treatises of government; collections of novels; Pedro de Salazar; paratexts

Con la edición de las catorce novelas conocidas de Pedro de Salazar, acaso de entre 1560 y 1570 y contemporáneas, por tanto, a El Patrañuelo de Timoneda, quedan ahora mejor definidas las líneas y tendencias de la incipiente práctica de la colección de relatos durante el siglo XVI, o más específicamente hasta 1580, cuando comienzan a publicarse de modo sistemático las traducciones de los novellieri italianos, verdadero pórtico editorial al género de la novela corta. ${ }^{1}$ Un modelo que queda definitivamente acrisolado como conformación literaria y en cuanto que género editorial tras la aportación cervantina en 1613. Curiosamente será Straparola quien inaugure y cierre ese periplo, mediante sendas ediciones en 1580 y $1612 .^{2}$ Desde luego, la mitad de siglo (1550-1560) habrá de funcionar como punto crucial para las mutaciones más trascendentales de los esquemas narrativos precedentes, con la emergencia de propuestas novedosas o renovadas, que conocemos como libros de pastores, novela bizantina o novela picaresca, etc. Siempre poniendo la vista, asimismo, en el Índice de Valdés de 1559, que censurará algunas de las obras emergentes, valga el Lazarillo, pero que además opera en contra de ciertos textos del xvi todavía muy cercanos a la tradición medieval. ${ }^{3}$

1. Un panorama para el Siglo de Oro puede verse en Laspéras (1987) y Pedrosa (2004).

2. González Ramírez (2011).

3. Como las «Obras de burlas que están en el cancionero general en lo que toca a devoción y cosas cristianas y de Sagrada Escritura» (Cathálogo de los libros en romance que se prohíben, 54), Plácida y Victoriano de Encina (51) o las continuaciones celestinescas (50, 52). Véase Alcalá (2001: 106-253). 


\section{Trayectorias y tradiciones}

Hasta esos años de mediados del XVI, en efecto, predomina y se perpetúa en la práctica de la colección de relatos la tendencia medieval, con la edición de los compendios hispanos en su vertiente occidental. Así, aparecen en las prensas, con numerosas reediciones renacentistas, los cuentos de Pedro Alfonso, El Calila $e$ Dimna y el Sendebar, a los que hay que sumar El conde Lucanor. En efecto, veintidós cuentos de la Disciplina clericalis se tradujeron en la Quinta sección de fábulas de La vida del Ysopet con sus fábulas historiadas, de 1482, ${ }^{4}$ donde se mezclan de modo absolutamente heterogéneo con algunas facecias de Poggio Bracciolini (los relatos I, II, X, XX, XXI, C). A su vez, el Exemplario sobre los engaños y peligros del mundo, versión del Calila hecha por Pedro Capua, apareció en $1493^{5}$ e incluso se vertió al italiano, con importantes manipulaciones estructurales y añadidos, por parte de Firenzuola, La prima veste dei discorsi degli animali (1548), y Doni, La moral filosophia (1552). Finalmente, el Libro de los siete sabios de Roma, trasunto latino del Sendebar, se editó en $1510,{ }^{6}$ y en un proceso curioso de ida y vuelta, la Historia lastimera del príncipe Erasto (1575) traducía I compassionevoli avvenimenti d'Erasto (1542), dando lugar a una colección que mantiene el entramado básico del encuadramiento pero que sustituye muchos de los cuentos, algunos de ellos por novelitas a la italiana, conformando un interesante producto híbrido. Sin embargo, el caso de El conde Lucanor resulta un tanto desemejante, porque la edición a cargo de Argote de Molina es muy tardía, de ese mismo año de 1575, por más que las manipulaciones en el orden secuencial de los textos, acorde a unos parámetros semánticos determinados, se simplifique en una sucesión sin enclaves organizativos. En definitiva, casi todas las versiones de los modelos orientales aligeran el componente estructural de las series narrativas proporcionando colecciones más sintéticas. Y dentro de esa misma tendencia hispánica podrían tenerse en cuenta las ediciones del Bonium o Bocados de oro (1495) y el Libro de los doze sabios (Tratado de la nobleza y lealtad, 1502), representantes máximos de los compendios sapienciales de sentencias y proverbios, la otra faceta de la prosa didáctica en la Edad Media.

Además, otras dos obras no exactamente definib les como colecciones de relatos, pero sí contenedoras de muchos cuentos con función de marco narrativo superior, tendrían que conocer cabida en esta tradición hispana, como ocurre con el Libro del caballero Zifar (1512) o el Corbacho (1498), sin olvidar tampoco la Historia de la doncella Teodor (ca. 1500-1503), muy cercana a los constructos sapienciales. Porque en realidad la mayoría de las compilaciones de cuentos (del

4. También con ediciones incunables en 1488,1489 , y 1496 .

5. Doce ediciones en el XvI: 1509, 1515, 1521, 1531, 1534, 1546, la última exenta en 1547, además de las ediciones conjuntas con el Ysopete historiado, 1541, 1546, 1550, 1621.

6. Desde 1530, 1538, 1583, 1595, hasta dieciocho ediciones. 
Calila a don Juan Manuel o el Zifar) son a su vez antologías de sentencias más o menos articuladas o combinadas con ellos. Esta literatura sapiencial funciona, asimismo, como ejemplificación en los Regimientos de príncipes, tales como los «Castigos del rey de Mentón» en el propio Zifar, o los Castigos del rey don Sancho $I V$, que constituyen encuadres organizativos de relatos, de forma parecida a como lo es también el Barlaam e Josafat. ${ }^{7}$ Por su parte, la otra tendencia fundamental para la constitución del libro de novelas viene dada por la traducción y asimilación del Decamerón de Boccaccio, prohibido en el índice valdesiano ${ }^{8}$ un conjunto de signo muy distinto, desde luego, sin excluir tampoco las propuestas de concurso narrativo dentro del Ninfale de Admeto o El Filocolo, aunque su adaptación castellana sea posterior, más la reinterpretación a la postre de traducciones italianas de los libros hispánicos de origen oriental, según se ha visto.

Una tercera vía de modelización de las series narrativas conoce un origen latino, aparte, en cualquier caso, de las tradición esópica ya mencionada, y se concreta sobre todo en una obra de gran divulgación europea, los Gesta romanorum, recreados en numerosas lenguas y ocasiones. Por ańadidura, aunque ya no una colección de relatos propiamente dicha, la lectura del Asno de oro, en versión española desde 1513, hubo de constituir, con su amplia inclusión de novelitas, una suerte de modelo de cómo insertar historias secundarias en una estructura de mayor alcance. De hecho, existe un testimonio que así parece confirmarlo. En el Prólogo sumario de La Pícara Justina se dice que la protagonista "fue dada a leer libros de romance [...] Y ansí, no hay enredo en Celestina, chistes en Momo, simplezas en Lázaro, elegancia en Guevara, chistes en Eufrosina, enredos en Patrañuelo, cuentos en Asno de oro, y, generalmente, no hay cosa buena en romancero, comedia, ni poeta español cuya nata aquí no tenga y cuya quinta esencia no saque». ${ }^{9}$ Una referencia a Apuleyo que parece fundarse en la coletilla al título en la traducción de Cortegana de 1513, donde se incide en que «[...] se contienen muchas historias y fábulas alegres [...]»

Ante esta persistente y renovadora reedición de los textos patrios y la traducción o versión de los foráneos no es posible admitir entonces que la compilación de patrañas de Timoneda $(1567,1576,1578,1580)^{10}$ sea el primer caso y prácticamente el único del libro de relatos en el siglo Xvi, puesto que él mismo incorpora textos de tales tradiciones precedentes, aunándoles, eso sí, la recreación, muchas veces compuesta, de textos provenientes de los novellieri postboccaccianos, que no fueron demonizados en los índices de libros prohibidos españoles, aunque sí en los italianos y portugueses. ${ }^{11}$ En este sentido, resulta preciso concluir que aunque la traducción sistemática de las colecciones italianas

7. Véase Haro Cortés $(1995,2003)$.

8. Cathálogo de los libros en romance que se prohiben, p. 58.

9. López de Úbeda, La pícara Justina, p. 81.

10. Citaré solo Cuartero Sancho (1990: 3-49).

11. Vega Ramos (2013). 
comience a ser un hecho editorial en torno a 1580, ya en las décadas anteriores se habían elegido algunas de estas novelas para su uso literario, tal como hace Timoneda y como ocurre igualmente con los Contos e Historias de Trancoso (1575), un compendio no español, pero sí peninsular, que obtuvo asimismo un éxito considerable $(1585,1589,1596,1608,1624,1633)$ y que comparte con El Patrañuelo los cuentos I, 17; II, 5; II, 7. Así pues, Timoneda acudió a los Gesta romanorum para las patrañas 5, 17, 21 y 22; al Decamerón en 2, 10 (inserta en el Calila), 15, y acaso 22; a los novellieri en 3, 9, 12, 18, 21, y a Bandello en particular para 7 y 19 , sin olvidar a Apuleyo en el caso de la 20. ${ }^{12}$

Sirva este apretado recorrido hasta mediados del siglo Xvi para llegar a la conclusión de que Pedro de Salazar con sus novelas se inserta en esa misma tendencia de hibridación de modelos y síntesis de las trayectorias previas, aunque añadiendo un importante elemento estructurador que lo retrotrae a los esquemas hispánicos con estructuras didácticas muy subrayadas: porque dota de un marco narrativo a la serie de cuentos, frente a Timoneda o Trancoso, compiladores de sus textos sin un sostén argumental, tónica que llegará a Cervantes y también al Fabulario de Sebastián Mey del mismo año que las Novelas ejemplares (1613). ${ }^{13}$ Ese Fundamento de los cuentos, y sobre todo la Dedicatoria del libro a Felipe II, constituyen la base programática del conjunto, una reflexión metaliteraria que ninguna de las colecciones mencionadas, salvo acaso la Disciplina clericalis y el Calila e Dimna, ha incorporado. A consecuencia de ello se entiende su importancia para la evolución de la colección de relatos en España y de la historia misma de la ficción áurea y su estatuto genérico frente a otras manifestaciones literarias, a más de por ser botón de muestra de los gustos lectores del monarca e indicio de las problemáticas relaciones de la prosa de imaginación con la imprenta.

\section{Discursos de legitimación}

Frente a Timoneda, constante promotor editorial de la literatura de entretenimiento de su tiempo, incluida la suya propia, Salazar encara la labor novelística desde los parámetros de su condición primordial de historiador y cronista, aunque no oficial, por más que al parecer lo pretendiera. ${ }^{14}$ Ese constituye, en efecto, el rasgo distintivo más destacable en su autoría de relatos ficticios y desde esa

12. Tamariz por su lado recibe influencias de Salernitano, Straparola, Bandello, Giovanni Florentino, Boccaccio, etc. Véase Tamariz, Novelas en verso.

13. Para este panorama, téngase en cuenta Núñez Rivera (2013). Ahí se encuentra la bibliografía pertinente por extenso, que, por tanto, no refiero aquí.

14. Véase Federici (2012). En la Dedicatoria de 1548 se refiere a ellos, en oposición a su papel de aficionado: «[...] no pocas vezes pensé ofrecerle esta hobra y servirle con ella mas tornándolo a pensar muchas vezes detúveme de lo hazer [compilar y escribir los sucesos y triunfos del emperador], considerando el cuidado que desto haurán tenido los reales coronistas que por oficio tienen de las imperiales historias de su magestad» (s. f.). 
polaridad entre historia y ficción ha de encararse entonces la conceptuación de las consignas artísticas e ideológicas que los amparan. En efecto, Salazar narró recurrentemente los hechos victoriosos de Carlos $\mathrm{V}$ en tres obras impresas, la primera sobre la guerra de Alemania en $1548^{15} \mathrm{y}$ otra segunda sobre la conquista de la ciudad de Mahdia, $1552^{16}$. Además, en una etapa posterior, ya muy cercana a su muerte (1576) apareció la Hispania vitrix (Medina del Campo, Vincente de Millis, 1570), que recogía con afán recopilador y también reivindicativo ${ }^{17}$ algunas de esas empresas militares y añadía otras (de entre 1546-1565). ${ }^{18}$ Las dos crónicas iniciales las dirigió Salazar a Felipe II todavía príncipe ${ }^{19}$ y la última se la dedica siendo ya rey. Del mismo modo, y con idéntico propósito de congraciarse con él, le ofrece como servicio el libro de novelas que compuso acaso (o que compiló definitivamente) en la década de 1560-1570, por tanto, entre las dos etapas cronísticas. ${ }^{20}$ Precisamente su hijo Eugenio confirma en torno a 1600 cómo la prestación continua a la corona ha sido la finalidad de todos estos escritos, los históricos, claro, pero también, y eso es lo más significativo, tal como recalca el propio hijo («y escribir (como también escribió) un agradable libro de novelas o cuentos»), el libro de recreación:

[...] historiar las memorables victorias de vuestro imperial abuelo invictísimo [...] y escribir (como también escribió) un agradable libro de novelas o cuentos con que sirvió a su magestad en el tiempo de su felicísima juventud, obra adaptada para alguna recreación y entretenimiento de aquella su edad dorada $[\ldots]^{21}$

15. Historia y primera parte de la Guerra que don Carlos, Quinto Emperador de los Romanos, Rey de España y Alemania, movió contra los Principes y Ciudades rebeldes del Reyno de Alemania y sucessos que tuvo... (Nápoles, Pablo Suganappo, 1548).

16. Hystoria de la guerra hecha contra la ciudad de África... (Nápoles, mastre Matia [Mattia Cancer de Brescia], 1552.

17. Fundado en la perpetua entrega personal: «Suplico a Vuestra Real Magestad humildísimamente, pues las otras mis obras a recebido con benignidad, con la mesma reciba agora ésta perdonando mi atrevimiento, pues continuo en mí queda muy mayor voluntad y desseo de le más servir» (s. f.). Como ya confirmaba en 1552: «[...] no contento ni satisfecho de parar allí, como desde entonces para siempre, yo mesmo propuse en mí de continuo ocuparme en su real servicio con ánimo, lengua y manos, y con todos mis pensamientos, palabras, obras comencé a llevar adelante mi voluntad y desseo" (s. f.).

18. Para todos los aspectos materiales y de contenido que se refieren en adelante ha de tenerse en cuenta mi edición de Pedro de Salazar, Novelas, y como adelanto, Núńez Rivera (2010). Descubrió la obra Blecua Perdices (1983).

19. La obra de 1548 se la entregó ese año personalmente al príncipe, según dice él mismo en la Dedicatoria de 1552: «Y por esto en Génova le presenté una parte de los esclarecidos triunfos que el gran César nuestro señor hubo de los poderosos y bravos germanos» (s. f.).

20. Dice: «[...] me atreví a Vuesa Majestad con la Historia y primera parte de la guerra que el cristianísimo e invictísimo Emperador, vuestro padre, que de Dios goza, movió contra los rebeldes del imperio, e después con la Crónica de la famosa conquista de África, e, agora, por tercera vez, me atrevo con la presente obra [...]» (122).

21. Eugenio de Salazar, "Qui navigant mare enarrant pericula eius»: La navegación del alma, pp. $69-70$. 
Cuando el propio Salazar escribe para el rey el Prólogo y dedicación de esta serie de novelas se podría argüir que se acoge a una fórmula argumentativa muy semejante a la recusatio retórica de que usan los poetas líricos para legitimar su labor poética al presente, en lugar de dedicarse al canto épico. ${ }^{22}$ Esta recusación de la poesía épica, la más elevada de todas, supone por razonamiento a la contra la dignificación de una modalidad menos prestigiosa y codificada, esto es, la poesía lírica. De igual modo, entonces, la propuesta novelesca de Salazar, pertinente ahora por su efecto terapéutico en el rey, sumido en sus quehaceres políticos, se iguala al ejercicio elevado e incontestable de la Historia. Una práctica historiográfica que, según él aúna el imponderable de la veracidad con el deleite que produce la magnitud de los acontecimientos. ${ }^{23}$ De esta forma las siguientes palabras del autor se han de entender como un discurso de legitimación de la práctica de la ficción novelesca, un ejercicio comúnmente denostado por los intelectuales y los moralistas:

Bien pudiera servir a Vuesa Majestad con la Segunda parte de la guerra de Alemania $\mathrm{y}$ con otros comentarios de otras guerras y batallas, que vuestro imperial padre emprendió y acabó prósperamente [...] Mas, considerando que, en la sazón presente, $\mathrm{V}$. M. tiene más nescesidad de lecturas que le recreen que de leer las variedades y peligros de la guerra [...] determiné de servirle con la obra presente, que es de cuentos, que los italianos llaman novellas, y antiguamente en Castilla llamaron consejas, por los buenos consejos y ejemplos que de ellos colegirse pueden (123-124). ${ }^{24}$

La argumentación legitimadora de Salazar se apoya en el razonamiento de más amplio espectro por muy repetido ${ }^{25}$ de que el hombre, y por supuesto el rey, se ha de solazar con las lecturas de recreación para conseguir evadirse del trabajo diario:

Y cierto, los cuidados de V. M. son de tanto peso y los negocios que de vuestra real persona penden tantos y de tanto tomo, que no sería justo darle más pesadumbre, y la que

22. Véase solo Ramajo Caño (1998).

23. En la Dedicatoria de 1570 queda explicado así: «Y así, recogido y recopilado, no teniendo ojo a otro que a decir y narrar simplemente la verdad, prosiguiendo en lo que antes de agora, que es servir como servía a V. M., con la historia de la guerra que movió la SCCRM del Emperador Carlos Quinto, vuestro muy amado y reverenciado padre Nuestro Señor, de buena y gloriosa memoria, que de Dios goza, a los rebeldes al sacro imperio y de la toma y presa de África (demás del libro intitulado de cuentos) lo puse en historia, la cual de más de ser (como es) verdadera lleva consigo una muy grata delectación» (s. f.).

24. Todas las citas van por Salazar, Novelas.

25. Sirva de ejemplo, por significativo, la traducción del prólogo de Amyot a Eliodoro, al que me refiero en adelante: «[...] la imbecilidad de nuestra natura no puede sufrir que el entendimiento esté siempre ocupado a leer materias graves y verdaderas, no más que el cuerpo no podría durar sin intermisión al trabajo de muchas obras. Por lo cual, es menester algunas veces, cuando nuestro espíritu está turbado de algunos infortunios, o cansado de mucho estudio, usar de algunos pasatiempos para le apartar de tristes pensamientos y imaginaciones» (LXXVII-VIII). 
estas cosas le acarrean. Y para sobrellevar tan pesados cargos como estos, conveniente, y aun nescesario, le es a tiempos honestamente recrearse, pues está claro que no se puede conservar la vida humana con el continuo trabajo [...] Y así mi fin principal ha sido ofrecer a V. M. esta lectura para alguna recreación de vuestro real entendimiento [...] (126).

Ahora bien, el deleite del monarca no puede obtenerse a partir de cualquier naturaleza literaria sino solo desde un honesto entretenimiento: ${ }^{26}$ los relatos, así pues, deben constituirse como honestas ficciones ejemplares, según ya señaló antes el autor: "por los buenos consejos y ejemplos que de ellos colegirse pueden". Este prurito de honestidad y ejemplaridad en las acciones novelescas queda confirmado mediante una tradición de autoridades que ya obraron en tal sentido, mientras que contrasta asimismo con la práctica desvergonzada de Boccaccio, el máximo ejemplo de la novela europea. Se trata, pues, de conseguir situarse en un punto jerárquico superior al género novelesco a la italiana, ${ }^{27}$ ejerciendo sobre la creación una especie de autocensura reguladora del decoro estilístico.

Con la mención de los Padres de la Iglesia y de más autores del pasado todos foráneos, pero ninguno patrio, Salazar se está autoproclamando hábilmente como iniciador de esta fórmula literaria ("puesto que ningún español, que yo sepa, hasta agora haya escrito en este género de escritura...", 124), de suerte, en efecto, parecida a como lo harán después, recalcando la inexistencia de una tradición española, Luis Gaytán de Vozmediano, traductor de la Primera Parte de las cien Novelas de M. Ivan Baptista Giraldi Cinthio, 1590 (Prólogo al lector, "en el de su traducción que ya que hasta ahora se ha usado poco en España este género de libros» ${ }^{28}$ ) y a la postre el propio Cervantes; "que yo soy el primero que he novelado en lengua castellana; que las muchas novelas que en ella andan impresas, todas son traducidas de lenguas extranjeras, y éstas son mías propias, no imitadas ni hurtadas». ${ }^{29}$ Proclamaciones ambas que mostrarían su respectivo desco-

26. Eugenio de Salazar sostiene que las novelas escritas por su padre «tienen ingenio y gustoso y honesto entretenimiento".

27. En cuanto a lo primero el autor constata que: «[...] es notorio que de muchos tiempos atrás otros muchos y muy graves autores aprobaron y usaron el escribir cuentos, y otros consejas y novelas, como arriba dije, de los cuales fue uno el excelente doctor San Jerónimo, el cual en sus Epistolas escribió a Eustoquia, noble virgen romana, cosas de donaire y pasatiempo, para que de mejor gana las leyese y más a la memoria las encomendase. Y San Gregorio, también doctor sagrado, mezcló ejemplos y cuentos graciosos en los diálogos que escribió a su discípulo Pedro Diácono» (124). Y respecto al novelista italiano resalta cómo sobrepasó el límite de la honestidad, mientras que él, practicando un poderoso ejercicio de autocensura, subraya el carácter ejemplar de estas novelas suyas: «E usaron también estas maneras de escribir Remigio y Aviano, y el Boccaccio, autores estraños de la nación española. Aunque este, en muchas cosas escedió los límites de la honestidad, los cuales con cuidado he yo procurado no traspasar, porque si las obras semejantes a esta mía, antiguamente, como he dicho, se llamaban consejas, por los buenos consejos y ejemplos que de ellas emanaban, no se podrían llamar tales las mías, si de ellas se pudiese tomar cosa contra honestidad y buen ejemplo» (125).

28. González Ramírez (2012).

29. Miguel de Cervantes, Novelas ejemplares, p. 9. 
nocimiento de las novelas de Salazar. Esta apuesta de Salazar por la obtención del recreo del monarca, en orden a su promoción literaria y acaso como cronista regio, quizá se amparen, y así se muestra en algunas Dedicatorias a reyes, en el conocimiento de la apetencia lectora del propio rey desde muy joven. ${ }^{30}$ Porque el propósito de amenizar sus ratos de ocio se adecua perfectamente a la demanda de entretenimiento por parte de Felipe tras sus agotadoras jornadas de trabajo, si hacemos caso de la referencia del cronista Esteban de Garibay en una carta a él dirigida en 1570 e inserta en su Quarenta Libros del Compendio Historial, donde dice: «Pide VM, concluidos los negocios, le den algún libro, y a vezes qualquiera que más a mano se hallare, como me consta de relaciones de criados suyos» ${ }^{31}$. Bien es cierto que Garibay se inclina, por el contrario de Salazar, a ofrecerle una historia de sus vastos dominios como mejor forma de distracción.

En correspondencia con este testimonio sobre la general avidez lectora de Felipe II, ${ }^{32}$ entre los anaqueles de su Librería rica (1535-1559), y por tanto de carácter personal, pueden identificarse hasta cinco libros de caballerías. ${ }^{33}$ Desde luego, ese montante representa un porcentaje exiguo (el 5\%) frente a la proporción de libros de Teología (29\%) y de Historia $(21,7 \%)$, pero muestra en todo caso el interés regio por la literatura de entretenimiento. ${ }^{34}$ En la casa real española existían otros lectores de libros de caballerías, como Isabel la Católica, que posee varios libros artúricos, y asimismo Carlos V y su esposa Isabel (de los cuales hereda los libros Felipe II), quienes según anécdotas recogidas por Luis Zapata en su Miscelánea, se solazaban en las siestas con la lectura de estos textos por parte de alguna dama. ${ }^{35}$ En otras dos bibliotecas nobiliarias del siglo XVI se constata, asimismo, una importante presencia de la literatura de ficción. Por ejemplo, en la del II Duque de Alburquerque, muerto en 1526, el número de libros de caballerías (treinta volúmenes) y de ficciones sentimentales (cinco títulos) resulta extensísimo, de modo que están presentes casi todos los volúmenes publicados en el primer cuarto de siglo, lo cual implica una compra casi sistemática por parte de un gran amante de la lectura. ${ }^{36}$ Asimismo, don Alonso Osorio, Marqués de Astorga, reunió una biblioteca (1573-1593) con una destacadísima presencia de la prosa caballeresca (veinticuatro volúmenes) además de otros géneros novelescos, incluyendo las colecciones de novelas de Boccaccio, Giraldi Guic-

30. Véase Sánchez-Molero (1998).

31. En Cuart Moner (2004: 45-126).

32. Lucía Megías (2008: 103-106).

33. Sánchez-Molero (1998). Los items: 100, Libro del noble y esforzado caballero Reinaldos de Montalbán, Sevilla, 1545; 874, Pedro de Luján, Docena parte del Amadís, 1546; 1180, Rodríguez de Montalvo, Los cuatro libros del Amadís, 1531; 1181, Sergas de Esplandián; 1277, Feliciano de silva, Florisel de Niquea, 1546.

34. Para fundamentar las correspondencias entre dedicatorias y bibliotecas véase Chartier (1997).

35. Sánchez Molero (2005: 204-208).

36. Ruiz García-Carceller Cerviño (2002). 
ciardini y Masuccio. ${ }^{37}$ Ambas bibliotecas ratificarían, además, con los datos de la realidad que la librería de don Quijote, lejos de ser una entelequia, responde a los gustos lectores de muchos hombres de la época.

En oposición a estos hábitos lectores imparables, las consignas de los moralistas del tiempo van por otros derroteros, al insistir en los perjuicios éticos que proporciona la lectura de imaginación, particularmente de los textos caballerescos. Los testimonios son innumerables. Sarmati (1996) ha reunido nada menos que noventa $\mathrm{y}$ tres referencias desde 1517 a 1666. Incluye, por ejemplo, el primer veto que hace Antonio de Guevara en el Prólogo General del Relox de principes (1529), dirigido a Carlos V, que se extiende a los libros de caballerías y a la ficción sentimental:

No sin causa digo que muchos libros merescían ser rotos o quemados, porque ya $\tan$ sin vergüença y $\tan$ sin conciencia se componen oy libros de amores del mundo como si enseñassen a menospreciar el mundo. Compassión es de ver los días y las noches que consumen muchos en leer libros vanos, es a saber: a Amadis, a Primaleón, a Duarte, a Lucenda, a Calixto, con la doctrina de los quales osaré dezir que no passan tiempo, sino que pierden el tiempo, porque allí no deprenden cómo se han de apartar de los vicios, sino qué primores ternán para ser más viciosos. ${ }^{38}$

Sin embargo, no reseña otro reproche incluso más ajustado a nuestro propósito, como es el de Felipe de la Torre, quien concluye el capítulo IV (Qué libros han de leer los reyes y señores, ff. 21v-26) de su Institucion de un rey christiano (1556), dedicada a Felipe II, ${ }^{39}$ con el aviso de la lectura de los libros religiosos, especialmente la Biblia, y otros en romance de piedad y de Historia, como al cronista Pedro Mexía o a Fox Morcillo, autor del De regno et regis institutione (1550):

Que los libros que están escritos de amores, y los que llaman de Cavallerías, no solamente los huyan los Reyes y Señores, y todos, finalmente, pero aun con edicto público prohiban su leción a todos, por ser inútiles los tales para todo género de virtud [...] porque corrompen a los buenos ingenios y los llevan hechizados en sus vanidades, destruyen las buenas costumbres, y encienden y hazen abrasar a los que las leen en abominables pecados $(25 \mathrm{v}-26) .^{40}$

37. Cátedra (2002: 217-222).

38. Fray Antonio de Guevara, Relox de Principes, pp. 38-39.

39. Para los tratados del período resulta fundamental Truman (1999), que los divide en varias secciones. Los editados en Amberes (Fox, el propio Torre y Furió, todos citados arriba); los destinados a regidores y corregidores, que no tengo en cuenta; los publicados en Aragón (Marco Antonio de Camós y Requeséns, Microcosmia y goviemo universal del hombre christiano, para todos los estados y qualquiera de ellos, Barcelona, Pablo Malo, 1592; Tomás Cerdán de Tallada, Verdadero govierno desta monarchia, tomando por su proprio subiecto la conservación de la paz, Valencia, Viuda de Pedro de Huete, 1581) y los de jesuitas (Pedro de Ribadeneyra, Tratado de la religión y virtudes que ha tener el príncipe christiano para governar y conservar sus estados, contra lo que Nicolás Maquiavelo y los políticos deste tiempo enseñan, Madrid, Emprenta de Pedro Madrigal, 1595; Juan de Mariana, De rege et regis institutione libri III, Toledo, Pedro Rodríguez, 1599).

40. Asimismo recoge la posterior del Aviso de Privados, publicado, 1539: «O quan desuiada esta 
Se constata en varios otros testimonios este mismo sentido que propone de la Torre de que las obras susceptibles de ser leídas por el rey y, por tanto, las únicas que podrían dedicársele para su beneplácito, son las de tipo histórico (por su veracidad) o las de aliento épico o guerrero, por su elevación argumental y estilística. ${ }^{41}$ Así, desde luego, en esa misma década de 1560, Ercilla dedica al monarca la Araucana (1569) o se le endereza la traducción del Orlanso furioso (1564) hecha por Urrea, "Que tracta el libro de altos hechos y heroicas y grandes empresas, a que V A es tan inclinado» (s. f.), además de, por ejemplo, una obra moral como la Philosophía vulgar de Mal Lara (1568), con una gran proporción de material apotegmático en su interior. Ahora bien, en oposición a la tónica de menosprecio dominante o la exclusiva sanción de los géneros prestigiados, la defensa de Salazar se ve refrendada por otra serie de textos inmediatamente anteriores o prácticamente contemporáneos que abogan por el ejercicio y recepción de la prosa de entretenimiento. El más trascendente de todos, por su función programática, en oposición al estatuto de la Historia, acaso sea el prólogo de Amyot a la versión francesa de las Etiópicas, ${ }^{42}$ traducida en España en 1554, que respalda, aunque con restricciones, una ficción verosímil, honesta y bien escrita, es decir la que conocemos como novela bizantina, procedente de Eliodoro, frente a los libros de caballerías, representantes de un modo antiguo: ${ }^{43}$

$\mathrm{Ni}$ tampoco se le puede dar [a la Historia] tanta ayuda con buena lengua y artificio de elocuencia, que ella tenga tanta fuerza de recrear el entendimiento del que la lee como un cuento ordenado a placer de industria para delectar, cuando es subtilmente inventado o ingeniosamente escripto y contado [...] Lo cual espero que en alguna manera se podrá hallar en esta fabulosa Historia de las fortunas de Cariclea y Teágenes. En la cual, además de la ingeniosa ficción, hay [...] las pasiones y afecciones humanas, pintadas tan al verdadero y con tan gran honestidad, que no se podrá sacar ocasión de malhacer. Porque de todas aficiones ilícitas y deshonestas, él hace el fin desdichado; y, al contrario, de las buenas y honestas, dichoso (LXXVIII-LXXX) ${ }^{44}$

oy la república de lo que aquí escriuimos y aconsejamos, pues vemos, que ya no se ocupan los hombres sino en leer libros que affrenta nombrarlos, como son Amadis de Gaula, Tristán de Leonis, Primaleón, Cárcel de amor, y a Celestina [...]». (ed. 1657, 3v-4).

41. Sánchez Marcos (2007) ha llegado, por ejemplo, a la conclusión de que el $42 \%$ de obras historiográficas del siglo XviI va dedicado a los monarcas.

42. Resulta fundamental Fumaroli (2007).

43. Exactamente: «Lo cual es al contrario en la mayor parte de los libros de esta suerte que han sido antiguamente escritos en nuestra lengua española, demás de que no hay ninguna erudición, ningún conoscimiento de antigüedad ni cosa alguna, por decir verdad, de la cual se pueda sacar algún provecho, mas antes están las más veces tan disonantes y tan fuera de verdadera similitud, que paresce que sean antes sueños de algún enfermo que desvaría con la calentura, que invenciones de algún hombre de espíritu y sano juicio. Y, por tanto, me paresce que no pueden tener gracia ni fuerza de delectar a un buen entendimiento, porque no son dignas dél porque es una cierta señal que aquél no tiene sentimiento ni conoscimiento de las cosas ingeniosas y gentiles, que se deleita de las bastas y groseras», LXXX.

44. Reproducido en Historia etiópica de los amores de Teágenes y Cariclea. Traducida en romance por Fernando de Mena, pp. LXXVII-LXXXIII. 
En virtud de esos parámetros justificativos no duda entonces el librero Claudio Bornat, que había editado el Orlando de Urrea, en dedicar la Selva de aventuras (1565) de Jerónimo de Contreras a Isabel, la esposa de Felipe II, "por la común utilidad que della se puede sacar y por la grande recreación de ánimo que en ella se puede hallar [...] Estos son los provechos y aun muchos más desta Selva de aventuras» ${ }^{45}$ Pero incluso el mismo Bornat, no obstante, en su edición un año antes de un libro de caballerías, el Olivante de Laura (de Antonio de Torquemada), dirigida al propio Felipe II, hace una rendida alabanza del género denostado e intenta justificar esta dedicatoria regia: ${ }^{46}$

¿Y qué cosa hay más digna de ser leída de los reyes que la historia, de la cual tantos avisos y ejemplos de virtud, así civil como bélica, así para la paz como para la guerra, se sacan? Como aun V. M. puede ver por esta dulce historia de Olivante de Laura, que entre otros libros antiguos de Francia truje, y la hice traducir de lengua griega en castellana, pareciéndome que era digna de venir a las reales manos de $\mathrm{V}$. M. porque con ella tuviese alguna recreación y entretenimiento entre tan grandes y justas ocupaciones como V. M. tiene en la administración de tantos reinos y señoríos, y en la defensión de la santa fe católica. Es historia muy dulce y apacible y llena de cosas muy hazañosas y de varios acaecimientos y hechos casi increíbles de príncipes de gran valor y ánimo (s. f.).

Y existen varios casos más en España, como las dedicatorias de Feliciano de Silva en el Florisel de Niquea, Parte, IV, libro I (1551), a María de Austria; Jerónimo López, en el Floramante de Colonia (1550); Clarián de Landanis, libro III (1524), a Juan III de Portugal; Beatriz Bernal, Cristalián de España (1545), a Felipe II. ${ }^{47} \mathrm{Y}$ también en las traducciones francesas tan abundantes en la década de 1550 a 1560, como en el Primer libro de la Crónica del muy valiente y temido Don Florís de Grecia también llamado el caballero del Cisne, que Herberay des Essarts dirige 1552 por primera vez en un prólogo apologético al rey Enrique II. ${ }^{48}$ En definitiva, a través de estas referencias, muchas veces encontradas, pero al cabo relativas todas ellas al problema moral de la ficción, conviene calibrar en su medida el afán de Salazar por dotar de decoro a su obra novelesca. En este proceso de dignificación la voz del autor no ha de enjuiciarse como un hecho aislado, al menos en los primeros años del reinado de Felipe II, sino que va en paralelo a la exculpación generalizada del modelo bizantino, el más refrendado por los humanistas en virtud de su pedigrí clásico y su alto contenido ejemplar, y por eso

45. Contreras, Selva de aventuras, p. 9.

46. Tengo que dar las gracias a M. Carmen Marín por haberme brindado su comunicación inédita «Estrategias de legitimación autoral en los paratextos femeninos áureos: las dedicatorias regias». 47. Eisenberg (1982:111-118).

48. Fumaroli (2007) también se refiere al Noveno libro de Amadís de Gaula, llevada a cabo por Claude Colet (París, 1553) y al Décimo Libro de Amadis en 1555, el Treceavo Libro (1571) y el Catorceavo Libro (1575) por Gohory, todos ellos con prólogos y dedicatorias apologéticas. 
en un estatus jerárquico superior, situado muy de cerca de la dimensión épica. ${ }^{49}$ Pero igualmente se asocia a ciertas defensas de los libros de caballerías, género comúnmente atacado por sus perjuicios morales y estéticos, pero apetecido ávidamente por los lectores, el rey incluido. No obstante, el recurso legitimador más hábil en el programa literario del autor parte de la concepción del conjunto de relatos como una suerte de regimiento de príncipes, adaptado a las necesidades lectoras del rey y construido en torno a un monarca visigodo.

\section{La herencia especular}

Entre los volúmenes de la Librería rica de Felipe II se guardaba también un $\mathrm{Ca}$ lila e Dimna manuscrito que procedía de su biblioteca infantil, conformada en especial por libros de mano entre 1534-1538. Debió de heredarlo de su abuela la reina Isabel, en cuya biblioteca se custodiaban además varios Ysopetes manuscritos y otros tantos impresos, más de cuatro manuscritos de los Bocados de oro o los Consejos del conde Lucanor y nada menos que quince Regimientos de principes. ${ }^{50} \mathrm{La}$ abundancia de estas lecturas de carácter apológico concuerda con su valor como componente pedagógico, tal cual se recomienda, por ejemplo, en el espejo de Alfonso Ortiz, el Diálogo sobre la educación del principe don Juan, sobre todo «los apólogos y los poemas compuestos por Esopo, en los cuales la diversión y la ayuda moral se mezclan». ${ }^{51}$ Una referencia que tendría en cuenta, desde luego, la evolución del apólogo en el Renacimiento desde que empieza a cultivarse entre los humanistas italianos del siglo Xv, en un proceso donde se va oponiendo al concepto de fábula milesia con que quedan definidos los libros de caballerías, tal como se manifiesta de Vives a Alejo de Venegas, por ejemplo. ${ }^{52}$ La naturaleza y conceptuación del Calila o el Sendebar, y asimismo de los compendios sapienciales, en cuanto que regimientos de príncipes se confirma más allá de estos datos sobre las bibliotecas y lecturas regias gracias a la enorme cantidad de asientos en otras colecciones nobiliarias, tanto medievales como renacentistas. De las primeras suponen una preciosa muestra, por ejemplo, las de Alfonso Tenorio, adelantado de Cazorla, 1430 (Calila, Castigos de los filósofos Castigos de sabios); Don Pedro de Stúñiga, conde de Plasencia (Calila); Álvaro Pérez de Guzmán, Señor de Orgaz, 1482 (Conde Lucanor); Gómez Manrique, 1490 (Libro de enseñamientos y Castigos de Aristóteles a Alejandro), ${ }^{53}$ aunque la biblioteca medieval más especializada en literatura sapiencial parece ser la de D. Lorenzo Suárez de Figueroa conde de Feria y señor de la Casa de Villalba (1461), que además del Calila atesora los Castigos e

49. El mejor libro de caracterización general del género lo constituye González Rovira (1996). Más reciente, asimismo, Marguet (2004).

50. Ruiz (2004).

51. Sánchez-Molero (2013: 301-307).

52. Véanse al respecto Baranda (2007) y Gagliardi (2008).

53. Beceiro Pita-Franco Silva (1985); Antelo Iglesias (1991). Además, Caunedo del Potro (1991). 
documentos del rey D. Sancho IV; el libro del Conde Lucanor; el libro de los Doce Sabios; el libro del Espejo de los legos. ${ }^{54}$ Por su parte, en librerías del siglo XvI se puede apreciar, por ejemplo, la presencia de numerosos Esopos. ${ }^{55}$

$\mathrm{Ni}$ que decir tiene que en estas bibliotecas nobiliarias los ejemplares de los diversos espejos y regimientos principescos resultan ser moneda corriente, tanto en formato manuscrito como impreso. ${ }^{56} \mathrm{Y}$ es que esos libros especializados en la regencia del poder configuran un todo unitario junto con las compilaciones de cuentos y sentencias de la tradición medieval hispánica, conforme al corpus que se detalló antes. Porque es esta la función que, por ejemplo, entrañaban el Calila o el Sendebar en el contexto oriental de creación y también el propósito con que fueron traducidos en la corte alfonsí. Así pues, los textos sapienciales, y sobre todo el Calila, se ajustan en su entramado conceptual a la institución de los consejeros reales, con sus fidelidades o falsías, eje primordial de cualquier ejercicio de regimiento. ${ }^{57} \mathrm{Su}$ característica constitutiva proviene mayoritariamente, frente a los tratados especulares, del recurso de la ficción para dar cauce a la enseńanza de contenidos cortesanos. Una posibilidad que en el siglo XvI asume asimismo Antonio de Guevara en el Libro áureo de Marco Aurelio emperador (1532) o el Relox de principes (1537), a pesar de sus prevenciones, ${ }^{58}$ o también Francisco de Monzón en el Libro segundo del Espejo del perfecto príncipe cristiano, que quedó inédito. ${ }^{59}$ A ella se acoge igualmente Pedro de Salazar, como medio de añadir un plus de entretenimiento y mejor asimilación a la mera ejemplaridad.

El andamiaje ficticio que enmarca las novelas de Salazar viene constituido por dos principios de origen distinto pero que se hibridan en esta colección. Por un lado, elige la estructuración externa en décadas de cuentos $^{60}$ (exactamente treinta relatos ${ }^{61}$, aunque solo nos ha llegado la primera más restos de las otras dos ${ }^{62}$ proveniente del sistema boccacciano, tal como expresa él mismo en la Dedicatoria:

54. Moreno González (2013: 302-303).

55. Hernández González (1998), entradas: 1, 16, 18, 19, 26, 33, 45, 46, 48, 58, 61.

56. Para el Siglo de Oro son ilustrativos Fournès-Canonica (2011); Suárez Quevedo (2009).

57. Haro Cortés (1995, 2003). Además, Bizarri (1995) y Bizarri-Rucquoi (2005).

58. Al respecto, baste el clásico estudio de Redondo (1976). Además, Buescu (2009).

59. El libro primero se publicó en 1556.

60. Esta secuenciación en varias partes integradas por diez novelas se extiende desde Boccaccio (recuérdese un total de cien novelas) al Novellino de Masuccio Salernitano, que establece cinco secciones, hasta Margarita de Navarra o a Giraldi Cinthio, quienes dividen respectivamente el Heptameron en siete y en diez deca las Hecatommithi.

61. Ahora bien, el número de treinta novelas también conoce dos formulaciones renacentistas. Por un lado, Le cene de Anton Francesco Grazzini (il Lasca) y por otro, Le piacevoli e amorose notti dei novizi de Pietro Fortini, dividida en tres jornadas con diez novelas por sección. Las primeras novelas quedaron manuscritas hasta 1756, pero las de Fortini se editaron en 1555, por lo que fácilmente pudo conocerlas Salazar.

62. Exactamente cuatro más, descubiertas por Vallín-Avenoza (1992), pero identificadas como de Salazar en Núñez Rivera (2010). 
E puesto que, con la ayuda de Dios, mis cuentos llegarán a número de treinta, los he repartido en tres partes, para servir a V. M. con ellos en tres pedazos, porque de los ver todos juntos en un cuerpo no se harte y enfade, como suele acaescer a los que ven a la mesa, donde a comer se asientan, todos los platos y servicios juntos (126).

Pero, en lugar de asumir la reunión de otros tantos interlocutores en algún determinado espacio ameno para relatar sus cuentos, se acoge a un principio distinto, que suele denominarse como alivio de caminantes. Precisamente Cristóbal de Villalón en El Scholástico, otra obra de sentido especular, que se endereza a Felipe II siendo todavía príncipe, define las dos posibilidades en el capítulo IV, XVII: «[...] cuentos, fábulas y façeçias, con las quales se quieren recrear, y principalmente quando el convite se ha celebrado en un deleitoso huerto y jardín, el qual es lugar más aparejado para este género de recreación, como nos es agora a nosotros éste. Y acontece acaso que por no sentir la fatiga de algún largo camino procuran los hombres de usar este género de placer cuando van en compañía, porque con él se haze el cansancio del camino menos sentir». ${ }^{63}$

Por lo que respecta al argumento del marco en concreto, el rey visigodo Ervigio, un monarca histórico antecesor de Rodrigo, contrae una enfermedad tan severa que todos los médicos lo dan por desahuciado. Pero él se encomienda a Dios y poco a poco va restableciéndose. Para alcanzar la mejoría completa, uno de sus médicos le aconseja que se traslade desde Toledo a Granada para pasar el verano. Con el fin de recrearse en el camino, el rey les encarga a varios nobles y principales señores que le relaten "cuentos gustosos y apacibles». También instituye un premio para el mejor relato y nombra a cuatro jueces, entre obispos y nobles, para que dictaminen al respecto, por lo que funciona como presidente del jurado o concurso literario, tal como ocurre, de hecho, en el Decamerón. A pesar de todo, la temporalidad del encuadre narrativo, emplazado en la alta Edad Media, y los personajes que intervienen en él, el rey y sus cortesanos, difieren bastante de los esquemas italianos. La figura del monarca como eje de la narración y la de sus consejeros y caballeros, agasajándolo en sus pretensiones y deseos, o recalcándole las consecuencias éticas de las historias, se parecen más a los modelos enunciativos de las colecciones castellanas medievales. Precisamente, guarda ciertas concomitancias, al margen, desde luego, de la disparidad de contenidos, con el esquema marco de la versión occidental del Sendebar, donde los siete sabios narradores cuentan casos al Emperador, narraciones de las cuales comentan, tanto unos como otro, cuestiones a propósito de la situación.

Eso por lo que respecta al acto enunciativo que da lugar a los cuentos, porque la enmarcación del conjunto parece seguir sobre todo el modelo del Calila, ofreciendo cauce a una suerte de hibridismo oriental-occidental observable desde las versiones de las obras medievales. En efecto, la primera colección en castellano, el

63. Villalón, El Scholástico, p. 332. Así ocurre, por ejemplo, en los Coloquios de Palatino y Pinciano. 
Calila e Dimna, se caracteriza por poseer el marco más complejo de entre todos los libros de cuentos de procedencia oriental, ya que está constituido por encuadres sucesivos de distinta naturaleza, desde la búsqueda del libro en la India y su traducción al persa, hasta las posteriores recreaciones en el contexto árabe y finalmente por parte del rey Alfonso X. De modo ciertamente paralelo en Salazar, la Dedicatoria a Felipe II constituye, como en el Calila, el primer marco, de índole histórica o referente al autor, o más propiamente a las relaciones del autor con el rey, un vínculo especular, en cierta forma similar a la del Calila, puesto que, en el nivel de la ficción, el rey Ervigio es un trasunto previo del propio Felipe, modelo de comportamiento y de criterio, de quien resulta incluso antecesor en la monarquía de España, de la misma forma que los cortesanos que lo reconfortan a él en el camino reiteran la función lúdica de Salazar, quien escribe para solazar al rey prudente. La correspondencia entre sucesivos estratos temporales de carácter histórico tiene su origen último en las colecciones medievales, comenzando por la importancia de la figura del rey en cuanto que mandatario y receptor del acto narrativo, como ocurre, por ejemplo, en el Libro de los doce sabios, el Calila, o los Castigos de Sancho $I V$. Una superposición de materia ficticia y verdad histórica que potencia la propuesta aleccionadora al encauzarla mediante referencias a la autoridad regia.

Complementariamente, este protagonismo de Ervigio en el encuadre narrativo (más la mención a otros reyes godos a lo largo del libro) ha de incardinarse en la corriente de goticismo imperante en la época, un tema preferido de Felipe II y fomentado por sus cronistas oficiales, sobre todo en la obra de Ambrosio de Morales, donde se exalta el mito gótico como pilar ideológico de la monarquía. De este modo, Felipe, imbuido de esa herencia, se siente muy afín, por ejemplo, de San Hermenegildo, al que venera y toma como modelo de príncipe católico por antonomasia. Así pues, Salazar elige para su obra un argumento base que de seguro sabe que habrá de satisfacer al rey enormemente, y de tal modo no duda en establecer un puente constante entre los reyes visigodos y el monarca actual al que rinde pleitesía, una línea continua de descendencia que se comienza a ponderar desde el siglo Xv. Para la monarquía filipina, pues, los visigodos constituyen la esencia hispana (prisci hispani) y son la representación de una España casticista y cristiana, frente al peligro interno de los musulmanes y judíos o el exterior de alemanes y turcos, nacionalidades que, por lo general, aparecen caracterizadas negativamente en los cuentos. ${ }^{64}$

\section{Por una renovada ejemplaridad}

Con los espejos de príncipes se intenta regular entre otros muchos aspectos, de lo ético y religioso a lo político, el ocio del rey, encauzándolo por parámetros decorosos para su estado. Ese otium cum dignitate se convierte asimismo en la

64. Véase, por ejemplo, Estal (1961), Clavería (1973) y González Fernández (1986). 
máxima del programa literario de Salazar, toda vez que presenta sus novelas a Felipe II desechando los elementos más deshonestos de la tradición boccacciana. Y ello, por más que no se limite a dejar de lado los argumentos humorísticos («en esta obra haya algunas invenciones amorosas y otras materias de donaire e sal»), aunque, eso sí, curándose en salud al insistir en que procuró «escribir por términos tan moderados y palabras tan medidas» (125). De manera general se podría afirmar, a este tenor, que cinco de los diez cuentos que dan forma a la primera jornada pertenecen a la categoría humorística (I, II, V, IX, X), sin que falte tampoco el ingrediente boccacciano (v), mientras que otros tantos (III, IV, VI, VII, VIII) se ajustan al patrón de las invenciones amorosas, tal como afirma asimismo el autor. Este segundo paradigma, que por lo general da origen a las novelas más extensas de la serie (III, VI, VIII), se corresponde además con el patrón de la ficción bizantina, una de las facetas posibles, y acaso la única sujeta a los amores honestos, ${ }^{65}$ de las que Conrad Gesner categoriza en su Bibliotheca universalis, 1545, como historiae amatoriae ${ }^{66}$ frente a los textos de la sentimental o de su descendencia celestinesca. Y es que, en realidad, esta modalidad narrativa fue entendida por los diversos teóricos y preceptistas como una auténtica épica en prosa (González Rovira, 1996), en virtud de su elevación estilística y la verosimilitud de los argumentos, a la par de la admiratio lectora. De hecho, se erige en el nuevo género de ficción (la novela reformada como dice Fumaroli [2007]) para la enseñanza moral a partir de los comportamientos ejemplares de sus personajes. $\mathrm{Y}$ en tanto que muchos de los protagonistas son precisamente reyes y princesas (IV, VI, VIII) parece plausible extrapolar la trama de aventuras bizantinas a los contenidos propios del regimiento de príncipes. Aparte de estos monarcas, situados en el tercer nivel o caja china del interior de los cuentos, algunas de las novelas arrancan con la mención de reyes godos antecesores de Ervigio, y por tanto del rey Prudente, de modo que se refrenda el poderoso vínculo de la ley sucesoria. Así ocurre en el I («Acabada la guerra que en las Galias tuvo el rey Bamba, predecesor de vuestra alteza [...]», 137) y en el II («Reinando en estos reinos el rey Sisebuto, predecesor de vuestra alteza [...]», 166). O con una variante, en el III ( Felisbiano, el primero Papa que hubo de este nombre, ya vuestra alteza sabrá que, antes que la pontifical monarquía le fuese dada», 186).

Conforme al engranaje dialógico que sustenta la narración y recibo de cada uno de los cuentos, los comportamientos virtuosos o no de los personajes novelescos, y entre ellos los de los reyes o princesas protagonistas, conocen el enjuiciamiento del rey Ervigio al concluirse los relatos y las apostillas últimas de sus

65. Sobre amores profanos pero edificantes, Luis de Urreta, Historia eclesiástica, 1610 (González Rovira, 1991: 36).

66. Establece una división entre Historiae fabulosae (Caballerías, Calila, Decamerón) e Historia amatoriae (Piccolomini; Celestina; Etiópicas; Decamerón), por más que Boccaccio participe de las dos, acaso por su hibridismo constitutivo. Véase Durán Barceló (2004). 
consejeros. En este sentido, estos diálogos cifran la enseñanza ejemplar a modo de moraleja concluyente, de tal forma que suponen la formulación más clara del regimiento regio. $\mathrm{Y}$ es que la conjunción del rey con el ayuntamiento de sus consejeros comporta uno de los ejes vertebradores de cualquier instrucción principesca, dado que en la elección de los mismos, así como en el ejercicio del consejo prudente e imparcial se fundamenta la ejecución del buen gobierno. De tal modo es recurrente el problema del consejo desde los textos medievales, que, por ejemplo, Furió Ceriol le dedica completo El Concejo y Consejeros del Principe (1559), uno de los adoctrinamientos filipinos más influyentes y sin duda el de mayor repercusión europea, con varias traducciones. ${ }^{67}$

En adición a la peripecia amorosa de corte bizantino, con sus acostumbradas solturas y agniciones, detonante para los conflictos ulteriores, los temas medulares de la colección, de los cuales dimana el significado especular en mayor medida, por comparación con los tratados de esta naturaleza, consisten en problemas relativos a la aplicación del derecho y su práctica judicial (en el ámbito de la sucesión, la herencia o el matrimonio) y también a la vertiente moral y religiosa del comportamiento regio, a más de la actuación ética de los monarcas como ejecutores de la ley y gestores del gobierno, inmersos en las dispares conductas cortesanas. ${ }^{68} \mathrm{Al}$ final del siglo, por ejemplo, tendrá mucho predicamento el Tratado de la religión y virtudes que debe tener el principe cristiano, de Pedro de Rivadeneira (1595), cuyo libro segundo, después del marco previo sobre la religiosidad del rey, va dedicado a las virtudes del Príncipe Cristiano: justicia ( $\mathrm{v}$-XIV), en sus dimensiones económica y judicial; clemencia (xVIII y XIX), magnificencia (xx), templanza (XXI y XXII), prudencia (XXII-XXXIII) y fortaleza (xxxIVXLIII). ${ }^{69}$ Como cifra de muchos de estos argumentos, aunque no consiste en un cuento regio, los comentarios de Ervigio tras el relato de la novela VII (De cómo un caballero español, enamorado de una dama extrajera que vio en cierta romería, se fue a la servir y del suceso que en sus amores tuvo) se muestran como una pequeña poética del género de aventuras, ajustado a los criterios de verosimilitud, y a veces de anclaje histórico, aseo artístico, ejemplaridad e incluso providencialismo:

— [...] Veis ahí a Otenrico, que, siendo de tan poca edad, se atrevió a dejar los buenos tratamientos y regalos de su madre y a someterse a los peligros del espantable mar por ir a ver la que su corazón había herido. Y ella, después comenzada a tocar de la venenosa flecha, siendo también nińa regalada, delicada y de su natural temerosa, pospuso todo el regalo y temor y cobró osadía para se disponer a los peligros que se dispuso por complacer a quien amaba.

- Verdad es, serenísimo señor — dijo Leandro, arzobispo de Cartagena- que amor hace posibles cosas que parescen imposibles, empero, si Dios con su divina

67. Véase Scandellari (2005).

68. Un estupendo compendio de temas especulares ofrece Nogales Rincón (2006).

69. Véase Díaz Martínez (2000) y Truman (1999). 
clemencia no se apiadara de los dos amantes caído habrían en manos de los verdugos ejecutores de la pena de su pecado y liviandad (366).

Valgan estas reflexiones metapoéticas para subrayar lo temprano de los atisbos bizantinos de Salazar, cuando acaso no se había publicado todavía la Selva de aventuras (1565), sino únicamente el Clareo y Florisea (1552), aunque sí se han difundido algunos precedentes genéricos. ${ }^{70}$ Por lo demás, la novedad máxima atañe en este cuento VII, y asimismo en el VI (De cómo una princesa italiana fue cautiva por un cosario africano y ella cativó con su hermosura un gentil mozo espanol que padeció por ella muchas fatigas), concomitantes ambos en varios de sus extremos, a la incorporación de un tema que se convertirá en adelante en uno de los argumentos más repetidos, tanto en las obras extensas de corte bizantino como en las novelas en colección: el ataque de los cristianos y su cautiverio a manos de los corsarios infieles con el consecuente intento de violación o de su cambio de fe. Aunque todavía en estos textos de Salazar, en correspondencia con su cronología, los piratas son africanos o cartagineses y no turcos, como ocurrirá en los textos del xvi, sobre todo a partir de la batalla de Lepanto (1571). Esta situación de constante amenaza marítima supone, pues, una de las particularidades temáticas más atenidas a la realidad histórica.

Por su parte, los cuentos IV y VIII resultan más significativos que estos anteriores desde la perspectiva especular. En el IV (De una famosa hazaña que una reina y una princesa su hija hicieron y del dolor que por ello dos principes recibieron) se plantea el problema sucesorio de padre a hija, ${ }^{71}$ puesto que la princesa es única heredera y dos son los pretendientes que contienden por ella. $\mathrm{Su}$ enfrentamiento conduce al rapto de Briseida y motiva el suicidio aparente de madre e hija, además de dar lugar a la guerra entre los reinos. Esta trama conoce evidente paralelismo con los argumentos de la ficción sentimental, especialmente los de aquellas obras (Cárcel de amor o Grisel y Mirabella) en torno a los problemas de amor relativos a una princesa y al comportamiento del padre como juez de la causa, un entramado legal que nutre muchas de las obras medievales en correspondencia con la figura del rey legislador y garante supremo de la ley, idea asumida en todos los regimini. En cuanto al cuento vin ( $D e$ cómo por la maldad de un traidor un rey y un fiel vasallo suyo padecieron muchas fatigas y trabajos) los lances de amor, resueltos en matrimonios dobles, funcio-

70. Tales como La vida e historia del rey Apolonio, 1488 (recogida en Timoneda, patraña 11), Caviceo (Libro de los honestos amores de Peregrino y Ginebra, ca. 1510), la Quexa y aviso contra amor (1548) de Juan de Segura, Flores y Blancaflor, 1512 (que sustenta además la trama del Filocolo), sin omitir la impronta griega de muchas de las novelas del Decamerón (II, 4, 6, 7; III, 8, 9; IV, 4, $10 ; \mathrm{V}, 2,3,6$, etc.), un componente bizantino que se multiplica en los novellieri posteriores y que también caracteriza a El Patrañuelo.

71. El cuento II (De cómo un mozo no quiso fiar de su padre cierta hacienda que le daban y la confió de un amigo suyo) trata un caso legal de derecho sucesorio pero en un ámbito civil. 
nan como anclaje de base para el desarrollo de otros asuntos de tipo político ubicados en la Grecia clásica, con lo que ello puede aportar de paradigmático para los receptores. El contenido primordial se articula mediante la oposición entre el fiel vasallo de Jerjes, rey de Acaya, llamado Patroclo, y el traidor Palamides, que termina acusándolo falsamente. Estos enfrentamientos, conclusos con la entronización del tirano, dan lugar al exilio de Patroclo y al destierro del rey mismo, convertido en mendigo. De forma contraria, el estudiante Agesilao, en una segunda secuencia narrativa, resulta elegido rey de Boecia, adonde llegan finalmente los otros personajes, a punto de ser ajusticiados por él, cosa que no ocurre por la mediación de Fedra, la hija de Patroclo, casada con el rey. Así pues, las rencillas en la corte, la dificultad para gestionar los matrimonios regios, como en el cuento IV (porque todo comienza aquí por el rechazo de Jerjes a casarse con una princesa), emparentan esta historia con los posibles avatares del marco y aún del entorno filipino, por lo que adquiere un gran valor especular en tanto que advertencia de los peligros cortesanos. Pero en particular alecciona sobre la omnipotencia de los designios divinos, los únicos capaces de ensalzar o abatir a cualquier hombre, incluido el monarca. En este aspecto, precisamente, inciden los comentarios de Ervigio cuando concluye el relato: «-Trabajos y fatigas grandes padecía el buen Patroclo — dijo el rey, acabado el cuento- mas bien le galardonó Dios su servicio y también el rey Jerjes no le pagó mal en se casar con su hija, aunque cierto a su grande lealtad y fidelidad era todo debido» (421). El rey, como argumenta Furió Ceriol, consta de dos naturalezas, una humana e individual, y otra proveniente de la voluntad divina y que lo faculta para su condición pública de gobierno. ${ }^{72}$

Justamente, el cuento XI trata del castigo que envió Dios a un rey por sus pecados y soberbia y cómo se arrepintió y salió de ellos y procede de los Gesta romanorum, 59, recreado por Juan Manuel en el controvertido ejemplo LI. Aquí el rey soberbio y despreciativo del temor de Dios conoce la caída en una degradación física y moral (pareja a la que se da en el cuento viII) que lo incapacita como rey y que no queda restablecida hasta que no reconoce íntimamente su pecado. El desamparo divino lo certifica el comentario último de Ervigio, importantísimo en su definición de un príncipe cristiano con el beneplácito providencial:

-El ingrato desconocido - dijo el rey, acabado el cuento- que no conoce las mercedes que Dios le ha hecho ni le da gracias por ellas justísimamente merece padecer las adversidades y miserias que el Belerio padeció y mayormente aquellos que han venido a subir a estados reales y altivos en señoríos y otras cosas, porque en cuanto el hombre se vea en más alta cumbre tanto más está obligado a humillarse y ser grato a quien le ensalzó y encumbró que es Dios que le pudiera hacer el hombre más pobre y abatido que hubiera en los nacidos (497).

72. Scandellari (2005). 
La falta de propósito de enmienda conduce, sin embargo, a un irremediable castigo de muerte al soberbio conde protagonista de la novela XIV (Cuento de cómo un conde de Rensburg procuró mucho la muerte de un hijo de un caballero alemán y cómo no quiso Dios que hubiese efecto en su mal deseo), quien, por culpa de sus grandes conocimientos y saberes ${ }^{73}$ no alcanza la medida ni el límite en sus actuaciones, sobreponiéndose a los designios divinos, cuando intenta matar a toda costa a Federico, quien tras diversos avatares se convierte en rey por matrimonio con la princesa. Estos dos contramodelos de conducta ejercen su función aleccionadora excontrario, tan propia de los textos didácticos y de adoctrinamiento principesco. Porque el rey para poder gobernar a su pueblo primero ha de gobernarse a sí mismo y acomodarse a la mesura vital.

Desde los recurrentes ecos providencialistas, reguladores de las vidas de los personajes y emanados de la justicia divina, una de las preocupaciones constantes en la colección de Salazar, y por eso andamiaje semántico del todo, radica en la cuestión del derecho y la justicia y sus modos contradictorios de aplicación. El rasero legal resulta ser medida de muchos de los relatos, asumiéndose entonces la naturaleza primigenia de los cuentos medievales como casos litigiosos con inclusión de discursos forenses. Tan es así, que los cuentos I y x especialmente, pero también el II y el IX plantean un tema judicial, los primeros mencionados por describir un litigio en toda regla y reflexionar sobre las ambigüedades en la correcta aplicación del derecho, dando origen así a una cornice de calado procesal. ${ }^{74}$ Por ejemplo, el cuento I (De cierta cuestión que tuvieron con unos gentileshombres cuatro soldados que de la guerra venían) pone en solfa el proceso jurídico contra cuatro soldados que han matado a unos caballeros, a causa de la incompetencia del juez que lleva el caso, lo cual hace exclamar a Ervigio, ejerciendo su papel de rey legislador, propio de los espejos de príncipes: «-A todos los jueces que quisieren hacer cosas de hecho hallasen quien ansí supiese obviar sus temeridades como estos soldados las obviaron: no llegarían tantas veces sus injustos rigores a efeto" (164). A lo que responde uno de los nobles consejeros, mediante una propuesta de buen gobierno relativa a la administración de la justicia:

—Por tanto, sería muy bien — dijo el buen arzobispo Juliano- que los reyes los pongan en sus estados, y, pues, los jueces de quien se tenga crédito administraran justicia. Y en esto tuviesen espicial cuidado de informarse, porque, si los jueces no tienen el celo que deben, muchos serían por año los agravios y desatinos que harán en deservicio de Dios y daño del prójimo (165).

73. «—Dañosas son muchas veces las letras — dijo el rey—a los que se aprovechan mal de ellas y así fueron a ese desventurado de Doronspel, pues por saber lo que sabía le tomó ganas de saber lo que no debiera. Ese deseo le trujo por sus pasos contados a dar en la celada de su siniestro hado» (610). La soberbia regia, en este caso del conde, por la desmedida apetencia de conocimiento es tema propio de muchos textos didácticos medievales y característica de Apolonio, por ejemplo.

74. Por ejemplo, Rabell (2007). 
Mientras tanto, la contienda forense del cuento $\mathrm{x}$ (De cierto pleito y contienda que hubo entre tres hermosas ninfas y cómo fueron ante la diosa Venus que las juzgase y las sentencias que sobre ello se dieron) se emplaza en un tiempo mítico (pues remeda el juicio de Paris) y gira en torno a un caso de amores, aunque aquí también las palabras del rey parezcan aplicarse a las circunstancias de la institución jurídica de índole terrena:

- No ternía yo por mala habilidad la que entre las tres ninfas discerniese cuál mejor mereció a Hipólito. Ellas se metieron en mucho trabajo y el juez a quien demandaron justicia la hace tan pocas veces que a ninguna de ellas aliviara la pena el refigerio que de las sentencias les podría emanar (470).

Otra de las estrategias ejemplarizantes de los esquemas bizantinos se asienta en la modelación de un amor verdadero entre los protagonistas, quienes logran evadirse de los deseos concupiscibles hasta alcanzar el matrimonio cristiano, y ello tras haber superado innumerables pruebas y peligros. Pero a veces la institución matrimonial se ve resentida por la imposición paterna de una unión aberrante, como por ejemplo ocurre con la malmaridada y aun acusada injustamente de adulterio del cuento III (De cómo una moza principal fue falsamente acusada de adulterio y lo que sobre ello sucedió).${ }^{75}$ Las disposiciones legales de los edictos tridentinos llegan de este modo a las ficciones, que reflejan a veces propuestas no canónicas, como el matrimonio secreto de los cuentos VII y XIII (De cómo por culpa de su madre una doncella ilustre perdió la honra y padeció mucho trabajo), pero a la vez revelan la actuación modélica de diversas mujeres en cuentos como el VI o VIII. Y es que la cuestión femenina y el debido comportamiento cortesano y amoroso con las mujeres acapara en gran medida la atención de los regimientos de príncipes y de las colecciones de cuentos, tal como se puede atestiguar, por ejemplo, en varios de los capítulos del libro II del Relox de principes de Guevara. Por eso las trazas del amor indecoroso, propio de mujeres lascivas o engañadoras, queda enjuiciado desde el rasero moral, haciendo uso de la perspectiva misógina en aras de una propuesta edificante. Así, en el cuento v la burladora termina siendo burlada, en el xII el embaucado es el amador impertinente, por obra de la dama pretendida, y en el XIII el amor fuera del matrimonio queda penado con la vida eremítica de la protagonista y su reclusión final. Solo la sanción del matrimonio cristiano se admite, pues, como cauce para los casos y cosas de amor.

Cuando Salazar, en fin, se aplicó a la creación de este conjunto de novelas conocía perfectamente el común desdoro del género breve y la opinión adversa acerca de todos sus componentes. Aun así apostó por dirigírselas a Felipe II, una decisión valiente, por lo exclusiva, pues ninguna de las colecciones de relatos, sí de otras propuestas ficticias, como hemos tenido ocasión de ver, se enderezó nunca a

75. Recrea la novela II, 44 de Bandello, también seguida por Timoneda, Patraña 7 (engastados elementos de Le Porretane, 22 y de Bandello, I, 22, de la cual procede la Patrańa 19) y Alonso de la Vega, La duquesa de la Rosa (ed. de Timoneda, 1566). 
un monarca. ${ }^{76} \mathrm{El}$ amparo del rey, consumidor de ficciones al igual que gran parte de la nobleza, suponía la primera estrategia para la dignificación del género, pero a ella el autor sumó otros mecanismos valorativos, tales como la ideación de un marco narrativo emplazado en la Edad Media, con un protagonista regio e histórico, predecesor, entonces, del rey Prudente. Pero sobre todo, ya en el seno de las novelas, Salazar eligió el patrón de la ficción bizantina, de proporciones moralizantes, muchas de las cuales están protagonizadas por monarcas que aspiran a la virtud y la justicia, o se apartan de ellas, según qué casos. Mediante estas estrategias afirmativas la mera colección de relatos quedaba aupada, con el dechado de la tradición medieval, a la categoría del regimiento de príncipes, de modo que se dotaban de una elevación moral ausente en el modelo boccacciano, asumido también en parte, pero que sí planteaban los antiguos textos de la tradición hispana.

El rechazo de la obscenidad de Boccaccio otorgaba al texto una lectura adecuada, cifrada en el lector por excelencia y privilegiado del conjunto, el propio rey. En este sentido, la Dedicatoria de la colección significa no solo una petición de amparo regio o un agasajo, sino que subraya la condición de la obra como un género de escritura, es decir de un futuro producto editorial para el recreo privado y en voz baja: ${ }^{77}$ y por eso insiste Salazar en varias de las marcas y procedimientos para facilitar esa lectura. ${ }^{78}$ Acaso las prevenciones morales y la insistencia en una ejemplaridad manifiesta, por otro lado frecuentes en toda obra aleccionadora, constituyan, a la par, una estrategia de censura previa, con vistas a allanar la impresión del texto, un hecho que, paradójicamente, nunca se produjo, a pesar del trato con el impresor de Millis, que editó su Hispania vitrix, y estaba muy atraído en su oficio por las colecciones de entretenimiento. ${ }^{79}$ Sea como fuere, las treinta novelas de Salazar quedaron postergadas hasta ahora a la exclusividad y aislamiento del manuscrito.

76. Los Engaños y desengaños del profano amor fueron enderezados por José Zatrilla y Vico a Carlos II, si bien era él mismo conde y marqués y la obra tiene un marcado sesgo moral. El Inventario de Villegas (1565) sí se dirige a Felipe II, pero, aunque integre dos novelitas, parece que se conceptúa como un libro de poemas, según se advierte en los preliminares.

77. Lo ha subrayado Laspéras (1999).

78. Así: «Y porque algunos de los cuentos que escribo son largos, e no siempre cualquiera de ellos se podrá pasar y leer de vez, determiné numerarlos para que por sus números se puedan ir leyendo y pasando, y el que hubiere de dejar cuento comenzado para proseguir después la letura de él, lo deje al fin del número, e cuando a él vuelva, halle con más facilidad el lugar hasta donde había leído. E puesto que, con la ayuda de Dios, mis cuentos llegarán a número de treinta, los he repartido en tres partes, para servir a V. M. con ellos en tres pedazos, porque de los ver todos juntos en un cuerpo no se harte y enfade» (125-126).

79. Editó las Horas de recreación recogidas por Ludovico Guicciardino, noble ciudadano de Florencia, traducidas de lengua Toscana (Bilbao, Mathias Mares, 1586) y podría ser el traductor de las Historias trágicas ejemplares de Bandello, en cuya edición de 1589 puso una dedicatoria y asimismo pudo participar junto con su hermano Juan, que había costeado estas impresiones, en la propuesta de edición, presentando su licencia de derechos, que nunca llegó a realizarse, de la segunda parte de las Historias trágicas (en 1586) y la primera parte de las novelas de Francisco Sansovino (en 1584). Véase González Ramírez (2011: 1227-1228). 


\section{Bibliografía}

AlCALÁ, Ángel, Literatura y ciencia ante la Inquisición española, Madrid, Laberinto, 2001.

Antelo Iglesias, Antonio, "Las bibliotecas del otoño medieval: con especial referencia a las de Castilla en el siglo XV», Espacio, Tiempo y Forma, S. III, $H^{a}$. Medieval, 4 (1991), pp. 285-350.

BARANDA, Consolación, «El apólogo y el estatuto dela ficción en el Renacimiento», Studia Aurea, 1 (2007) <http://studiaaurea.com/article/view/v1-baranda>

Beceiro Pita, I. y Franco Silva, A., "Cultura nobiliar y bibliotecas: cinco ejemplos, de las postrimerías del siglo XIV a mediados del XVI», Historia, Instituciones, Documentos, 12 (1985), pp. 277-350.

Bizarri, Hugo O., «Las colecciones sapienciales castellanas en el proceso de reafirmación del poder monárquico (siglos XIII y XIV)», Cahiers de Linguistique Hispanique Médiévale 20 (1995), pp 35-71.

BizArri, Hugo O. y RucquoI, Adeline, «Los espejos de príncipes en Castilla: entre Oriente y Occidente», Cuadernos de Historia de España 79 (2005), pp. 7-30.

Blecua Perdices, José Manuel, "Notas para la historia de la novela en España», Serta Philologica F. Lázaro Carreter, Madrid, Cátedra, 1983, vol. 2, pp. 91-95.

Buescu, Ana Isabel, "Corte, poder e utopia: O Relox de Principes (1529) de Fr. Antonio de Guevara e a sua fortuna na Europa do século XVI», eHumanista, 12 (2009), pp. 145-181.

Cátedra, Pedro, Nobleza y lectura en tiempos de Felipe II: la biblioteca de don Alonso Osorio, Marqués de Astorga, Valladolid, Junta de Castilla y León, Consejería de Educación y Cultura, 2002.

Caunedo del Potro, Betsabé, "Un inventario de bienes de Gómez Manrique», Estudios de Historia Medieval en homenaje a Luis Suárez Fernández, Valladolid, Universidad, 1991, pp. 95-114.

Cervantes, Miguel de, Novelas ejemplares, Jorge García López (ed.), Barcelona, Crítica, 2001.

CHARTIER, Roger, «El príncipe, la biblioteca y la dedicatoria en los siglos XVI y XVII", Historiografía francesa. Corrientes temáticas y metodológicas recientes, Hira de Gortari y Guillermo Zermeño (eds.), México, Centro Francés de Estudios Mexicanos y Centroamericanos - CIESAS - IIH - UNAM - Instituto Mora - UIA, 1997, pp. 51-75.

Clavería, Carlos, "Notas generales sobre los godos y su proyección histórica», Cuadernos Hispanoamericanos, 280-282 (1973), pp. 541-556.

Contreras, Jerónimo de, Selva de aventuras, Miguel Ángel Teijeiro Fuentes (ed.), Cáceres, Institución Fernando el Católico/Universidad de Extremadura, 1991.

Cuart Moner, Baltasar, «La larga marcha hacia las historias de España en el siglo XVI», , La construcción de las Historias de España, Ricardo García Cárcel (ed.), Madrid, Marcial Pons, 2004, pp. 45-12. 
Díaz Martínez, E. M., "Tradición e innovación en los tratados de educación de príncipes de los siglos XVI y XviI. Una revisión del fenómeno", Analecta Malacitana 23, 2 (2000), pp. 493-519.

Durán BARCELó, Javier, «El orden de la ficción literaria en la biblioteca del monasterio de El Escorial», La memoria de los libros : estudios sobre la historia del escrito y de la lectura en Europa y América, Pedro M. Cátedra y otros (eds.), Salamanca, Cilengua. Centro Internacional de Investigación de la Lengua Española, Instituto de Historia del Libro y de la Lectura, 2004, 2, pp. 193-206.

EISENBERG, Daniel, "Dedications of the Spanish of Chivalry», en Romances of Chivalry in the Spanish Golden Age, Newark, Juan de la Cuesta, 1982.

Estal, Juan Manuel del, "Culto de Felipe II a San Hermenegildo", La ciudad de Dios, 77 (1961), pp. 523-552.

Federici, Marco, «Appunti sulla figura e sulla opera di Pedro de Salazar: storiografo, novelliere e cronista al tempo di Carlo V e Filippo II», Annali dell'Università di Napoli L'Orientale-Sezione Romanza, LIV, 2 (2012), pp. 123-132.

Fournès, Ghislaine y Canonica, Elvezio (eds.), Le Miroir du Prince. Écriture, transmission et réception en Espagne (XIII ${ }^{e}-X V I^{2}$ siècles), Bordeaux, Presses Universitaires de Bordeaux, 2011.

FumAroli, Marc, «La 'herencia de Amyot': La crítica de la novela de caballería y los orígenes de la novela moderna», Anales Cervantinos, 39 (2007), pp. 235-262.

Gagliardi, Donatella, "Malos libros en la España del xvi: la fábula milesia de Vives a Venegas», Studia Aurea, 3 (2008) <http://www.studiaaurea.com/ article/view/25>.

GonzÁlez Fernández, R., "El mito gótico en la Historiografía del siglo xv», Antigüedad y cristianismo: Monografías históricas sobre la Antigüedad tardía, 3 (1986) 289-302.

González Ramírez, David, «En el origen de la novela corta del Siglo de Oro: los novellieri en España", Arbor, 187, 752 (2011), pp. 1221-1243.

—, "En el origen de la novela corta del Siglo de Oro: los novellieri desde sus paratextos», Arbor, 188, 756 (2012), pp. 813-828.

GonzÁlez Rovira, Javier, La novela bizantina en la Edad de Oro, Madrid, Gredos, 1996.

Guevara, Fray Antonio de, Relox de Príncipes, Emilio Blanco (ed.), Madrid, ABL/CONFRES, 1994.

Haro Cortés, Marta, Literatura de castigos en la Edad Media: libros y colecciones de sentencias, Madrid, Laberinto, 2003.

—, Los compendios de castigos del siglo XIII: técnicas narrativas y contenido ético, Valencia, Universitat de València, 1995.

Hernández González, Ma. I., «Suma de inventarios de bibliotecas del siglo XVI (1501-1560)", en El libro Antiguo español IV. Coleccionismo y Bibliotecas (Siglos XV-XVII), Salamanca, Patrimonio Nacional, Universidad de Salamanca, 1998, pp. 375-446. 
Historia etiópica de los amores de Teágenes y Cariclea. Traducida en romance por Fernando de Mena, Francisco López Estrada (ed.), Madrid, Aldus, 1954.

Laspéras, Jean Michel, La nouvelle en Espagne au Siécle d'Or, Montpellier, Éditions du Castillet, 1987.

—, «La invención de la novela: hacia una definición», Jean Canavaggio (ed.), La invención de la novela, Madrid, Casa de Velázquez, 1999, pp. 307-317.

López de ÚbedA, Francisco, La picara Justina, Antonio Rey Hazas (ed.), Madrid, Editorial Nacional, 1977.

Lucía Megías, José Manuel, "Amadís de Gaula, un héroe para el siglo xXI», Tirant, 11 (2008), pp. 99-118.

MaRguet, Christine, Le roman d'aventures et d'amour en Espagne. XVI-XVII siècles. L’utile et l'agréable, Paris, L'Harmattan, 2004.

Moreno González, José María, Educación y cultura en una villa nobiliaria: Zafra 1500-1700, Huelva, Universidad de Huelva, 2013.

Nogales Rincón, David, «Los espejos de príncipes en Castilla (siglos XIII-Xv): un modelo literario de la realeza bajomedieval», Medievalismo: Boletín de la Sociedad Española de Estudios Medievales, 16 (2006), pp. 9-40.

Núñez Rivera, Valentín, "Las Diez novelas de Pedro de Salazar y los Cuatro cuentos de ejemplos. Autoría común y estructura compartida", Nueva Revista de Filología Hispánica, 58, 1 (2010), pp. 59-93.

-, «En los orígenes de la novela. Series narrativas con marco ficcional, entre abismos y reflejos», Ficciones en la ficción. Poéticas de la narración impresa (siglos XV-XVIII), Valentín Núnez Rivera (ed.), Studia aurea monografica, Barcelona, Universidad Autónoma, 2013, pp. 25-47.

Pedrosa, José Manuel, El cuento popular en los Siglos de Oro, Madrid, Laberinto, 2004.

Rabell, Carmen (ed.), Ficciones legales. Ensayos sobre ley, retórica y narración, Santiago de Chile-San Juan de Puerto Rico, Maitén, 2007.

Ramajo Caño, Antonio, "La Recusatio en la poesía de los Siglos de Oro», Actas del IV Congreso Internacional de la Asociación Internacional Siglo de Oro (AISO), (Alcalá de Henares, 22-27 de julio de 1996), María Cruz García de Enterría y Alicia Cordón Mesa (eds.), Alcalá de Henares, Universidad de Alcalá, 1998, vol. 2, pp. 1285-1294.

Redondo, Augustin, Antonio de Guevara (1480?-1545) et l'Espagne de son temps. De la carrière offcielle aux oeuvres politico-morales, Ginebra, Droz, 1976.

Ruiz García, Elisa, Los libros de Isabel la Católica. Arqueología de un patrimonio escrito, Salamanca, Gráficas Cervantes, 2004.

Ruiz García, Elisa y Carceller Cerviño, María del Pilar, «La biblioteca del II Duque de Alburquerque (1467-1526)", Anuario de Estudios Medievales, 32, 1 (2002), pp. 361-400.

SALAZAR, Eugenio de, "Qui navigant mare enarrant pericula eius»: La navegación del alma, Jessica C. Locke (ed.), México, El Colegio de México, Biblioteca Novohispana, 2011. 
Salazar, Pedro de, Novelas, Valentín Núñez Rivera (ed.), Madrid, Cátedra, 2014.

SÁnchez Marcos, Fernando, "Historiografía y dedicatorias en la monarquía hispánica del siglo XvII», Pedralbes, 27 (2007), pp. 17-34.

Sánchez-Molero, Gonzalo, La "Librería rica» de Felipe II: estudio histórico y catalogación, San Lorenzo del Escorial, Ediciones Escurialenses, 1998.

-, Regia Bibliotheca. El libro en la corte española de Carlos V, Mérida, Editora Regional de Extremadura, 2005, vol. 2, pp. 204-208.

-, Felipe II. La educación de un "felicísimo príncipe» (1527-1545), Madrid, CSIC/Polifemo, 2013.

SARMATI, Elisabetta, Le critiche ai libri di cavalleria nel cinquecento spagnolo (con uno sguardo sul seicento). Un'analisi testuale, Pisa, Giardini, 1996.

Scandellari, Simonetta, «El Concejo y Consejeros del Príncipe»: algunos aspectos de la literatura política española del siglo XVI», Res publica, 15 (2005), pp. 49-75.

SuÁrez Quevedo, Diego, «De Espejos de Principes y afines, 1516-1658. Arte, literatura y monarquía en el ámbito hispano", Anales de Historia del Arte, 19 (2009), pp. 117-156.

Tamariz, Cristóbal de, Novelas en verso, ed. Donald McGrady, Charlottesville, Universidad de Virginia, 1974.

Timoneda, Joan, El patrañuelo, María Pilar Cuartero Sancho (ed.), Madrid, Austral, 1990.

Truman, Ronald W., Spanish Treatises on Government, Society and Religion in the Time of Philip II: The 'De Regimine Principum' and Associated Traditions, Leiden, Brill, 1999.

Vega Ramos, María José, «La ficción ante el censor. La novella y los índices de libros prohibidos en Italia, Portugal y España (1559-1596)», Ficciones en la ficción. Poéticas de la narración impresa (siglos XV-XVIII), Valentín Núnez Rivera (ed.), Studia aurea monografica, Barcelona, Universidad Autónoma, 2013, pp. 49-75.

Villalón, Cristóbal de, El Scholástico, J. Martínez Torrejón (ed.), Barcelona, Crítica, 1997. 
